\title{
Mutual regulation of vasopressin- and oxytocin-induced glucagon secretion in V1b vasopressin receptor knockout mice
}

\author{
Yoko Fujiwara, Masami Hiroyama, Atsushi Sanbe, Junji Yamauchi, Gozoh Tsujimoto ${ }^{\mathbf{1}}$ and Akito Tanoue \\ Department of Pharmacology, National Research Institute for Child Health and Development, 2-10-1 Okura, Setagaya-ku, Tokyo 157-8535, Japan \\ ${ }^{1}$ Department of Genomic Drug Discovery Science, Graduate School of Pharmaceutical Sciences, Kyoto University Faculty of Pharmaceutical Sciences, Kyoto \\ University, Yoshida Shimoadachi-cho, Sakyo-ku, Kyoto 606-8501, Japan \\ (Requests for offprints should be addressed to A Tanoue; Email: atanoue@nch.go.jp)
}

\begin{abstract}
$\left[\mathrm{Arg}^{8}\right]$-vasopressin (AVP) and oxytocin (OT) are neurohypophysial hormones which exert various actions, including the control of blood glucose, in some peripheral tissues. To investigate the type of receptors involved in AVP- and OT-induced glucagon secretion, we investigated the effect of these peptides on glucagon secretion in islets of wild-type $(V 1 b R+/+)$ and vasopressin $V 1 b$ receptor knockout $(V 1 b R-/-)$ mice. AVP-induced glucagon secretion was significantly inhibited by the selective V1b receptor antagonist, SSR149415 (30\%), and OT-induced glucagon secretion by the specific OT receptor antagonist, $\mathrm{d}\left(\mathrm{CH}_{2}\right)_{5}\left[\mathrm{Tyr}(\mathrm{Me})^{2}, \mathrm{Thr}^{4}, \mathrm{Tyr}-\mathrm{NH}_{2}^{9}\right] \mathrm{OVT}$ (CL-14-26) $(45 \%)$, in islets of $V 1 b R+/+$ mice. AVP- and OT-induced glucagon secretions were not by the antagonist of each, but co-incubation with both $10^{-6} \mathrm{M}$ SSR149415 and $10^{-6} \mathrm{M}$
\end{abstract}

CL-14-26 further inhibited AVP- and OT-induced glucagon secretions in islets of $V 1 b R+/+$ mice $(57$ and $69 \%$ of the stimulation values respectively). In addition, both AVP and OT stimulated glucagon secretion with the same efficacy in $V 1 b R-/-$ mice as in $V 1 b R+/+$ mice. AVP- and OT-induced glucagon secretion in $V 1 b R-/-$ mice was significantly inhibited by CL-14-26. These results demonstrate that $\mathrm{V} 1 \mathrm{~b}$ receptors can mediate OT-induced glucagon secretion and OT receptors can mediate AVP-induced glucagon secretion in islets from $V 1 b R+/+$ mice in the presence of a heterologous antagonist, while AVP and OT can stimulate glucagon secretion through the OT receptors in $V 1 b R-/-$ mice, suggesting that the other receptor can compensate when one receptor is absent. Journal of Endocrinology (2007) 192, 361-369

\section{Introduction}

Arginine-vasopressin (AVP) and oxytocin (OT) are neurohypophysial hormones synthesized in the paraventricular nucleus and supraoptic nucleus of the hypothalamus. AVP acts in many organs and plays a variety of physiological roles, such as vasoconstriction (Schrier et al. 1993), glycogenolysis in the liver (Michell et al. 1979, Eugenin et al. 1998), adrenocorticotropic hormone (ACTH) release from the anterior pituitary (Gillies et al. 1982, Rivier et al. 1984, Hernando et al. 2001), and water reabsorption in the kidney (Nielsen et al. 1995, Ecelbarger et al. 2000). OT also plays crucial roles in uterine contraction (Fuchs et al. 1982, Goodwin et al. 1994) and milk ejection during lactation (Moos et al. 1989, Young et al. 1996). In addition to these physiological roles, AVP and OT are known to regulate the circulating blood glucose level by stimulating insulin and glucagon release (Dunning et al. 1984, Gao et al. 1990, 1991, 1992, Stock et al. 1990, Li et al. 1992, Gao \& Henquin 1993, Abu-Basha et al. 2002).

AVP- and OT-induced pancreatic hormone secretion, such as insulin and glucagon, is evoked by the activation of AVP and OT receptors expressed in pancreatic islet cells.
These AVP and OT receptors are seven transmembrane G-protein-coupled receptors and belong to the same family. This receptor family consists of the V1a, V1b, and V2 receptors and the OT receptor. Several studies have reported that the V1b and OT receptors are involved in insulin and glucagon secretion from a pancreatic cell line (Richardson et al. 1995, Yibchok-anun \& Hsu 1998) or isolated islets (Oshikawa et al. 2004). While insulin secretion by AVP (Richardson et al. 1995, Oshikawa et al. 2004) and OT (Lee et al. 1995) has been shown to be induced via the V1b receptor, previous studies with subtype-nonselective vasopressin receptor antagonists suggested that both the $\mathrm{V} 1 \mathrm{~b}$ and the OT receptors were involved in glucagon secretion by stimulation with AVP and OT (Yibchok-anun \& Hsu 1998, Yibchok-anun et al. 1999). Although both V1b and OT receptors are involved in the glucagon secretion, no one has analyzed this secretion when specific receptor is absent.

To elucidate the roles of the $\mathrm{V} 1 \mathrm{~b}$ receptor in glucagon secretion, we examined the mechanism of AVP- and OT-induced glucagon secretion using receptor-selective antagonists and V1b receptor knockout $(V 1 b R-/-)$ mice (Tanoue et al. 2004), in which tissue expression of the V1b 
receptor mRNA was undetectable (Oshikawa et al. 2004). First, we examined whether SSR149415, a recently developed V1b receptor-specific antagonist (Serradeil-Le Gal et al. 2002, Folny et al. 2003, Oshikawa et al. 2004), inhibited AVP- and OT-induced glucagon secretion from primary cultured mouse islet cells. We next investigated the involvement of the OT receptor in AVP- and OT-induced glucagon secretion using $\mathrm{d}\left(\mathrm{CH}_{2}\right)_{5}\left[\mathrm{Tyr}(\mathrm{Me})^{2}\right.$, Thr ${ }^{4}$, Tyr-NH $\left.{ }_{2}^{9}\right] \mathrm{OVT}$ (CL-14-26), an OT receptor-selective antagonist. Furthermore, we investigated glucagon secretion in $V 1 b R-/-$ mice with the antagonists. We show here that both the $\mathrm{V} 1 \mathrm{~b}$ and the OT receptors fundamentally mediate AVP- and OT-induced glucagon secretion respectively, and that signaling pathways through the OT receptor can mediate and compensate AVP-induced glucagon secretion when the $\mathrm{V} 1 \mathrm{~b}$ receptor is completely abolished.

\section{Materials and Methods}

\section{Materials}

Fetal bovine serum (FBS) was from Thermo Trace (Melbourne, Australia). Hanks' solution was from Nissui (Tokyo, Japan). AVP and OT were from the Peptide Institute (Osaka, Japan). $\left.{ }^{3} \mathrm{H}\right]$ AVP ([ Arg $\left.^{8}\right]$-vasopressin, [phenylalanyl-3,4,5- ${ }^{3} \mathrm{H}(\mathrm{N})$ ]; specific activity, $60 \cdot 0 \mathrm{Ci} /$ mmol) and $\left[{ }^{3} \mathrm{H}\right] \mathrm{OT}$ (OT, [tyrosyl-2,6- $\left.{ }^{3} \mathrm{H}\right]$; specific activity, $48 \cdot 0 \mathrm{Ci} / \mathrm{mmol}$ ) were from Perkin-Elmer Life and Analytical Sciences (Boston, MA, USA). SSR149415, which was the specific antagonist for the V1b receptor, was donated by Sanofi-Synthelabo (Montpelier, France). $\mathrm{d}\left(\mathrm{CH}_{2}\right)_{5}\left[\mathrm{Tyr}(\mathrm{Me})^{2}, \mathrm{Thr}^{4}\right.$, Tyr-NH$\left.{ }_{2}^{9}\right] \mathrm{OVT}$ (CL-14-26), which specifically antagonized the OT receptor (Elands et al. 1988, Kawamata et al. 2003), was a generous gift from Dr Maurice Manning (Medical College of Ohio). The RPMI 1640 medium, BSA, and diethylstilbestrol dipropionate (DES) were purchased from Sigma-Aldrich (Tokyo, Japan). Collagenase S-1 was purchased from Nitta (Osaka, Japan). Glucagon ELISA kits and all other chemicals were purchased from WAKO (Tokyo, Japan).

\section{Animals}

Male mice deficient in the V1b vasopressin receptor were generated by gene targeting as described previously (Tanoue et al. 2004). Briefly, by homologous recombination, we disrupted exon 1, which contains the translation initiation codon. The generated mutant mice were of a mixed genetic background of $129 \mathrm{~Sv}$ and C57BL/6. For this study, wild-type $(V 1 b R+/+)$ mice were used as controls and maintained on the 129Sv and C57BL/6 genetic background. All animals used in this study were 9-10 weeks old. Mice were housed in micro-isolator cages in a pathogen-free barrier facility $(12 \mathrm{~h}$ light:12 h darkness cycle) with access to regular chow and water available ad libitum. All experiments followed the institutional guidelines.

\section{Isolation of pancreatic islets and glucagon measurement}

Mouse pancreatic islets were isolated from male mice by collagenase digestion followed by Ficoll gradient separation as described previously (Shibata et al. 1976, Oshikawa et al. 2004). Briefly, the mouse pancreas was injected with an aliquot of $3 \mathrm{ml}$ Hanks' medium containing $2 \mathrm{mg} / \mathrm{ml}$ collagenase S-1 through the choledoch duct by clamping one side of the duct to block the flow into the intestinal tract. Pancreata were collected from four to five mice, and incubated at $37^{\circ} \mathrm{C}$ for $20 \mathrm{~min}$. The reaction was stopped by the addition of ice-cold Hanks' medium. The digested pancreata were washed with the same medium, filtrated through a Spectra-mesh $(408 \mu \mathrm{m}$; Spectrum Laboratories, Inc., Ft. Lauderdale, FL, USA), and washed with the same medium. The samples were resuspended in $4 \mathrm{ml}$ Ficoll (specific gravity, 1.22) and then overlaid twice with $2 \mathrm{ml}$ Ficoll with specific gravities of 1.09 and 1.05. After centrifugation at $2000 \mathrm{~g}$ for $10 \mathrm{~min}$, the islets were collected from the interface. The isolated islets were washed with an RPMI 1640 medium containing 10\% FBS, $11 \mathrm{mM}$ glucose, $50 \mathrm{U} / \mathrm{ml} \mathrm{penicillin}$, and $50 \mu \mathrm{g} / \mathrm{ml}$ streptomycin and preincubated for $2-3 \mathrm{~h}$ in the same medium at $37^{\circ} \mathrm{C}$ in $5 \%$ $\mathrm{CO}_{2}$. Fifteen islets were used for one assay, and experiments including three or four assays in one dose were repeated four to five times. After sampling of the baseline, AVP or OT stimulation was performed at $37^{\circ} \mathrm{C}$ for $10 \mathrm{~min}$. Arginine $(20 \mathrm{mM})$ was used as a positive control. Each antagonist was added $5 \mathrm{~min}$ before the stimulation with AVP or OT. After stimulation, the supernatant was taken up and the glucagon concentration was measured using the glucagon ELISA kit.

\section{Ligand binding assay}

Uterine tissues were isolated from female mice treated with DES $(0.3 \mathrm{mg} / \mathrm{kg}$ body weight) i.p., $20 \mathrm{~h}$ before isolation. Uterine cells stably expressing mouse $\mathrm{V} 1 \mathrm{~b}$ receptor were prepared as described previously (Oshikawa et al. 2004). Saturation binding studies were performed to incubate $20 \mu \mathrm{g}$ cell membrane and $50 \mu \mathrm{g}$ uterine membrane preparations with various concentrations of $\left[{ }^{3} \mathrm{H}\right] \mathrm{AVP}$ and $\left[{ }^{3} \mathrm{H}\right] \mathrm{OT}(0 \cdot 1-$ $5 \cdot(\mathrm{nM})$ in $250 \mu \mathrm{l}$ assay buffer containing $50 \mathrm{mM}$ Tris- $\mathrm{HCl}$ (pH 7•4), $10 \mathrm{mM} \mathrm{MgCl}_{2}$, and $0 \cdot 05 \%$ BSA. For competition binding studies, $1 \mathrm{nM}\left[{ }^{3} \mathrm{H}\right] \mathrm{AVP}$ and $2 \mathrm{nM}\left[{ }^{3} \mathrm{H}\right] \mathrm{OT}$ were added to cell membrane and uterine membrane preparations respectively, and incubated with various concentrations of compounds in $250 \mu \mathrm{l}$ assay buffer. The incubation condition in all binding studies was $1 \mathrm{~h}$ at room temperature. The reaction was stopped by an ice-cold wash buffer containing $50 \mathrm{mM}$ Tris- $\mathrm{HCl}(\mathrm{pH} 7 \cdot 4)$ and $5 \mathrm{mM} \mathrm{MgCl}_{2}$, filtered onto UniFilter-96 GF/C using a FilterMate Cell Harvester (Perkin-Elmer Life Science and Analytical Sciences). 

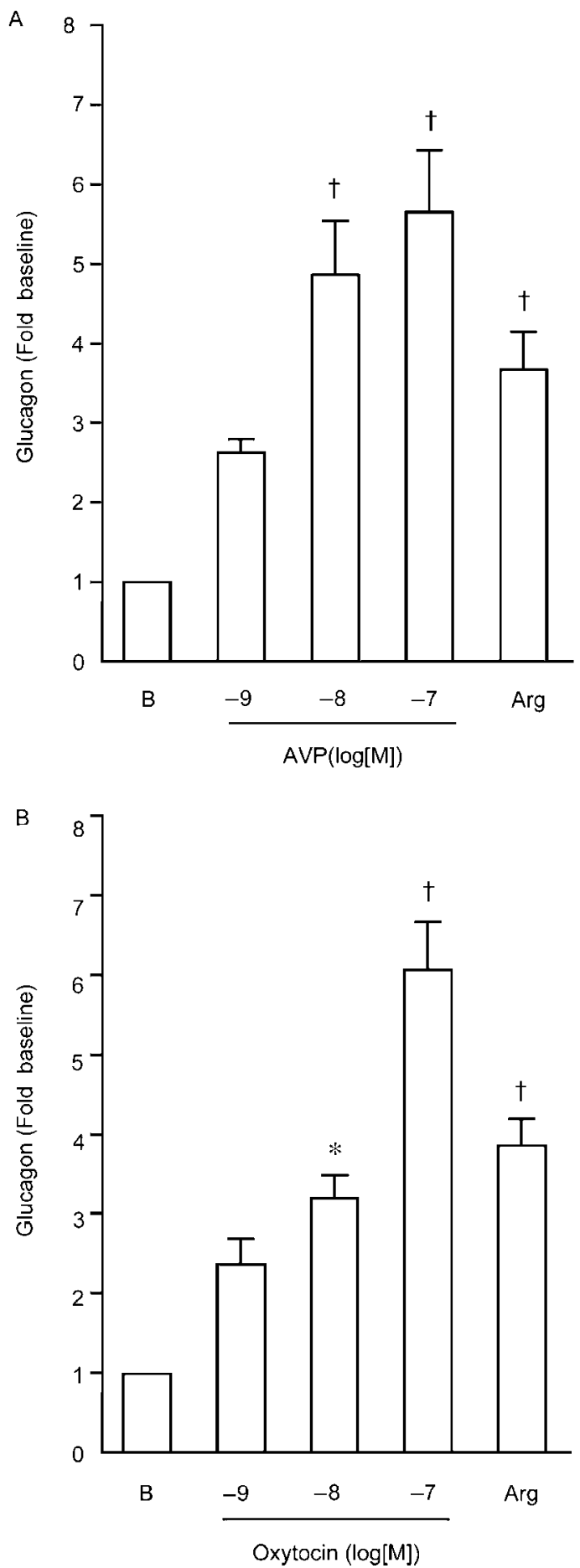

Figure 1 AVP- and OT-induced glucagon secretion from the islets of $V 1 b R+/+$ mice. (A) AVP-induced glucagon secretion. (B) OT-induced glucagon secretion. The experiments, which included three assays ( 15 islets for each assay), were repeated four to five times, and the mean values and S.E.M. were calculated. B, baseline; Arg, $20 \mathrm{mM}$ arginine. ${ }^{*} P<0 \cdot 01$ and ${ }^{\dagger} P<0 \cdot 001$ versus baseline in each stimulation by a one-way ANOVA post hoc comparison with Fisher's PLSD.
The filters were rinsed five times, and the radioactivity was measured using a TopCount Microplate Scintillation Counter (Perkin-Elmer Life Science and Analytical Sciences). Nonspecific binding was determined using $1 \mu \mathrm{M}$ unlabeled AVP and OT. Specific binding was calculated as the difference between total and nonspecific counts. The inhibitory $K_{\mathrm{d}}$ values $\left(K_{\mathrm{i}}\right)$ were calculated using the following formula (Cheng \& Prusoff 1973): $K_{\mathrm{i}}=\mathrm{IC}_{50}\left(1+[\mathrm{L}] / K_{\mathrm{D}}\right)$, where $\mathrm{IC}_{50}$ is the concentration of the test compound that caused $50 \%$ inhibition of specific binding, $[\mathrm{L}]$ is the concentration of the radioligand present in the assay, and $K_{\mathrm{D}}$ is the $K_{\mathrm{d}}$ of the radioligand obtained from Scatchard plotting. The binding data were analyzed by the iterative nonlinear regression program, LIGAND (Munson \& Rodbard 1980).

\section{Statistical analysis}

Data are expressed as means \pm standard error (S.E.M.). Statistical analysis was performed using the unpaired Student's $t$-test and the one- or two-way ANOVA followed by a post hoc comparison with Fisher's probable least-squares differences (PLSD) test using Statview version 5.0 software (Concepts, Inc., Berkeley, CA, USA). Differences between groups were considered statistically significant at the level of $P<0 \cdot 05$.

\section{Results}

AVP- and OT-induced glucagon secretion from the islets of $\mathrm{V} 1 \mathrm{bR}+/+$ mice

AVP increased glucagon secretion from the islets of $V 1 b R+/+$ mice in a dose-dependent manner (Fig. 1A). AVP-induced glucagon secretion in $V 1 b R+/+$ mice was five times the value at the baseline after stimulation of $10^{-8} \mathrm{M}$, which was a sufficient concentration to release glucagon under the conditions of this experiment (glucagon secretion at $10^{-8}$ vs $10^{-7} \mathrm{M}$ of AVP, $P=0 \cdot 39$ ). The basal glucagon concentration was $355 \cdot 1 \pm 59 \cdot 4 \mathrm{pg} / \mu \mathrm{l}$ in AVP-stimulation experiments. OT-induced glucagon secretion was six times that at the baseline at $10^{-7} \mathrm{M}$, which was a sufficient concentration to release glucagon in $V 1 b R+/+$ mice (the glucagon secretion at $10^{-8}$ vs $10^{-7} \mathrm{M}$ AVP, $P<0 \cdot 01$; Fig. 1B). Basal

Table 1 The receptor affinity of AVP, OT, and compounds for the $\mathrm{V} 1 \mathrm{~b}$ and the OT receptors (OTR)

\begin{tabular}{|c|c|c|}
\hline \multirow[b]{3}{*}{ Ligands } & \multicolumn{2}{|l|}{$\boldsymbol{K}_{\mathbf{i}}(\mathrm{nM})$} \\
\hline & $\mathrm{V} 1 \mathrm{~b}$ & OTR \\
\hline & & \\
\hline AVP & $2 \cdot 4 \pm 0 \cdot 2$ & ND \\
\hline OT & ND & $55 \pm 8 \cdot 1$ \\
\hline CL-14-26 & $7800 \pm 0 \cdot 8$ & $83 \pm 6 \cdot 1$ \\
\hline
\end{tabular}

ND, not determined. 

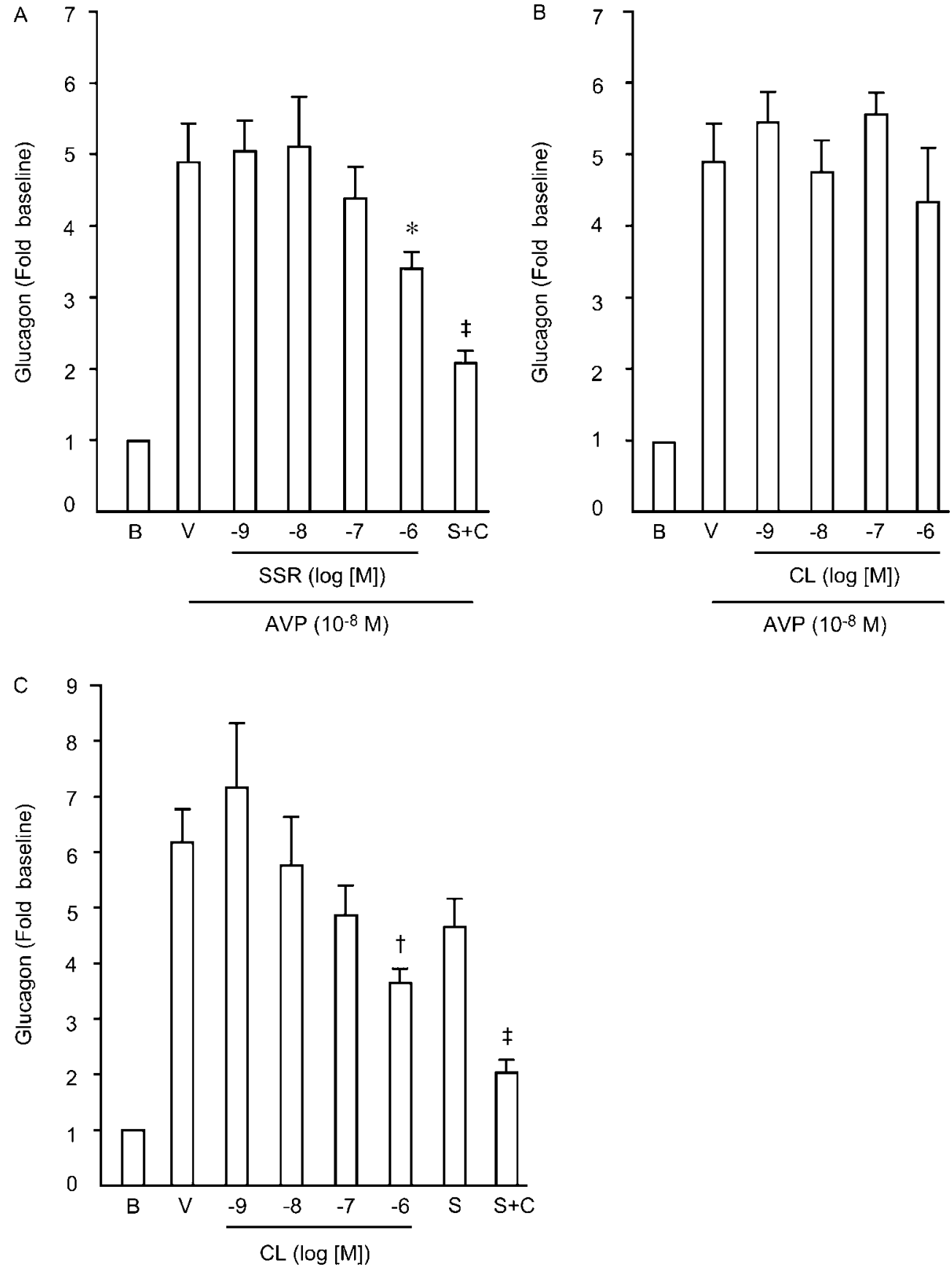

\section{Oxytocin $\left(10^{-7} \mathrm{M}\right)$}

Figure 2 Effects of the antagonist for the $\mathrm{V} 1 \mathrm{~b}$ and the OT receptors in $\mathrm{V} 1 \mathrm{bR}+/+$ mice. AVP-induced glucagon secretion treated with (A) SSR149415 or both SSR149415 and CL-14-26 and (B) CL-14-26. (C) OT-induced glucagon secretion treated with CL-14-26 or both SSR149415 and CL-14-26. The experiments, which included two or three assays (15 islets for each assay), were repeated five times, and the mean values and s.E.M. were calculated. B, baseline; V, vehicle; SSR, SSR149415; CL, CL-14-26; S, $10^{-6}$ M SSR149415; S+C, co-treatment at $10^{-6} \mathrm{M}$ with SSR149415 and CL-14-26. ${ }^{*} P<0 \cdot 05,{ }^{+} P<0 \cdot 01$, and ${ }^{\ddagger} P<0 \cdot 001$ versus vehicle treatment by a one-way ANOVA post hoc comparison with Fisher's PLSD. 
glucagon concentration was $386 \cdot 7 \pm 47 \cdot 4 \mathrm{pg} / \mu \mathrm{l}$ in OT-stimulation experiments. Glucagon secretion by arginine stimulation in this experiment was approximately four times that at the baseline and lower than that by AVP or OT stimulation (Fig. 1).

Analysis of AVP- and OT-induced glucagon secretion with receptor-selective antagonists in $\mathrm{V} 1 \mathrm{bR}+/+$ mice

Antagonists were used to identify the receptors involved in glucagon secretion from the islets of $V 1 b R+/+$ mice. We selected and used SSR149415 as a V1b receptor-specific antagonist that was used in a previous experiment (Oshikawa et al. 2004). In this study, we examined the specificity of CL-14-26 for a mouse OT receptor using a radioligand binding assay using the uterine plasma membrane of female mice treated with DES. The $B_{\max }$ was $0.4 \pm 0.02$ and $0.1 \pm$ $0.01 \mathrm{pmol} / \mathrm{mg}$ protein for the cell membrane expressing the $\mathrm{V} 1 \mathrm{~b}$ receptor and the uterine membrane respectively. The $K_{\mathrm{D}}$ values were $0 \cdot 3 \pm 0 \cdot 1$ and $0 \cdot 5 \pm 0 \cdot 07 \mathrm{nM}$, as obtained from Scatchard plot analysis ( $n=3$ in each experiment). The results of the competition binding analysis using AVP, OT, and antagonists are shown in Table 1 . The data showed that CL14-26 was a selective antagonist for the OT receptor rather than the V1b receptor, with $K_{\mathrm{i}}$ values of $83 \pm 6 \cdot 1(n=4)$ and $7800 \pm 0 \cdot 8(n=4) \mathrm{nM}$ for the OT and the $\mathrm{V} 1 \mathrm{~b}$ receptors respectively.

SSR149415 significantly inhibited AVP-induced glucagon secretion from the islets of $V 1 b R+/+$ mice at $10^{-6} \mathrm{M}$ (Fig. 2A). Around 30\% inhibition was observed at $10^{-6} \mathrm{M}$ SSR 149415, whereas, from $10^{-9}$ to $10^{-6} \mathrm{M}$, CL-14-26 could not significantly inhibit AVP-induced glucagon secretion from the islets of $V 1 b R+/+$ mice (Fig. 2B). Furthermore, the OT-selective antagonist, CL-14-26, significantly inhibited OT-induced glucagon secretion from the islets of $V 1 b R+/+$ mice at $10^{-6} \mathrm{M}$ (Fig. 2C). Around $45 \%$ inhibition was observed at $10^{-6} \mathrm{M}$ CL-14-26, whereas $10^{-6} \mathrm{M}$ SSR149415 tended to suppress OT-induced glucagon secretion, but not significantly (Fig. 2C). These results indicated that AVP and OT stimulated glucagon secretion through the $\mathrm{V} 1 \mathrm{~b}$ and $\mathrm{OT}$ receptors respectively, in $V 1 b R+/+$ mice.

Since AVP- and OT-induced glucagon secretion was not completely inhibited by SSR 149415 or CL-14-26 even at the highest concentration $\left(10^{-6} \mathrm{M}\right)$, we studied glucagon secretion further with a combination of the V1b and OT receptor antagonists. Simultaneous administration of SSR149415 and CL-14-26 synergistically inhibited AVPand OT-induced glucagon secretion at a concentration of $10^{-6} \mathrm{M}$ (Fig. 2A and C). The percentage inhibition of SSR149415 in AVP-induced glucagon secretion was increased from 30 to $57 \%$ in combination with CL-14-26. Similarly, the percentage inhibition of SSR149415 in OT-induced glucagon secretion was increased from 45 to $69 \%$ in combination with CL-14-26. There were no significant differences between the basal levels and either AVP or OT stimulation in combination with both
SSR149415 and CL-14-26 (one-way ANOVA; $P=0.52$ in AVP stimulation, $P=0.33$ in OT stimulation). These results suggested that AVP could stimulate glucagon secretion via the OT receptors, when the $\mathrm{V} 1 \mathrm{~b}$ receptor was blocked by SSR149415; and that OT could also stimulate it via the V1b receptors, when the OT receptor was blocked by CL-14-26.

$A V P$ - and OT-induced glucagon secretion from the islets of $\mathrm{V} 1 \mathrm{bR}-/-$ mice

We examined AVP- and OT-induced glucagon secretion from the islets of $V 1 b R-/-$ mice (Fig. 3). Not only OT but also AVP was able to stimulate glucagon secretion in $V 1 b R-/-$ mice in a dose-dependent manner, as observed in $V 1 b R+/+$ mice (Fig. $3 \mathrm{~A}$ and B). In $V 1 b R-/-$ mice, AVP- and OT-induced glucagon secretion was about six times that at the baseline at $10^{-7} \mathrm{M}$, which was a sufficient concentration to release glucagon under the conditions of this experiment (glucagon secretion at $10^{-8}$ vs $10^{-7} \mathrm{M}$ AVP, $P<0.05$; glucagon secretion at $10^{-8}$ vs $10^{-7} \mathrm{M}$ OT, $P<0 \cdot 01)$. The basal glucagon concentrations were $340 \cdot 8 \pm$ $52 \cdot 7$ and $339 \cdot 5 \pm 20 \cdot 8 \mathrm{pg} / \mu \mathrm{l}$ in AVP- and OT-stimulation experiments respectively. There were no significant differences in AVP- and OT-induced glucagon secretion between $V 1 b R+/+$ and $V 1 b R-/-$ mice $(V 1 b R+/+$ mice versus $V 1 b R-/-$ mice; $P=0.85$ for AVP-stimulation experiments, and $P=0 \cdot 81$ for OT-stimulation experiments by two-way ANOVA). Glucagon secretion by arginine stimulation in this experiment was approximately four times that at the baseline and lower than that by AVP or OT stimulation, similar to the observation in $V 1 b R+/+$ mice (Fig. 3). These findings suggested that AVP could stimulate glucagon secretion via a receptor(s) other than the V1b receptor in $V 1 b R-/-$ mice as potently as OT could.

Next, we examined glucagon secretion with antagonists to elucidate the receptors involved in AVP-induced glucagon secretion in $V 1 b R-/-$ mice. While $10^{-6} \mathrm{M}$ SSR 149415 could not suppress AVP- or OT-induced glucagon secretion, CL-14-26 could significantly inhibit AVP- and OT-induced glucagon secretion (Fig. 4). In particular, CL-14-26 could almost completely inhibit AVP-induced glucagon secretion at a concentration of $10^{-6} \mathrm{M}$ in $V 1 b R-/-$ mice, whereas it did not significantly antagonize AVP-induced glucagon secretion in $V 1 b R+/+$ mice. There were no significant differences between the basal level and either AVP or OT stimulation in combination with CL-14-26 in $V 1 b R-/-$ mice (one-way ANOVA; $P=0.50$ in AVP stimulation, $P=0 \cdot 12$ in OT stimulation). This suggested that AVP and OT stimulate glucagon secretion through the OT receptor in $V 1 b R-/-$ mice, in which a signaling pathway of the OT receptors could achieve optimal efficacy by stimulation of even OT and AVP.

We conducted further experiments to reveal the response to co-stimulation of AVP and OT in $V 1 b R+/+$ and $V 1 b R-/-$ mice. In $V 1 b R+/+$ mice, glucagon secretion by co-stimulation was higher than single stimulation of AVP 

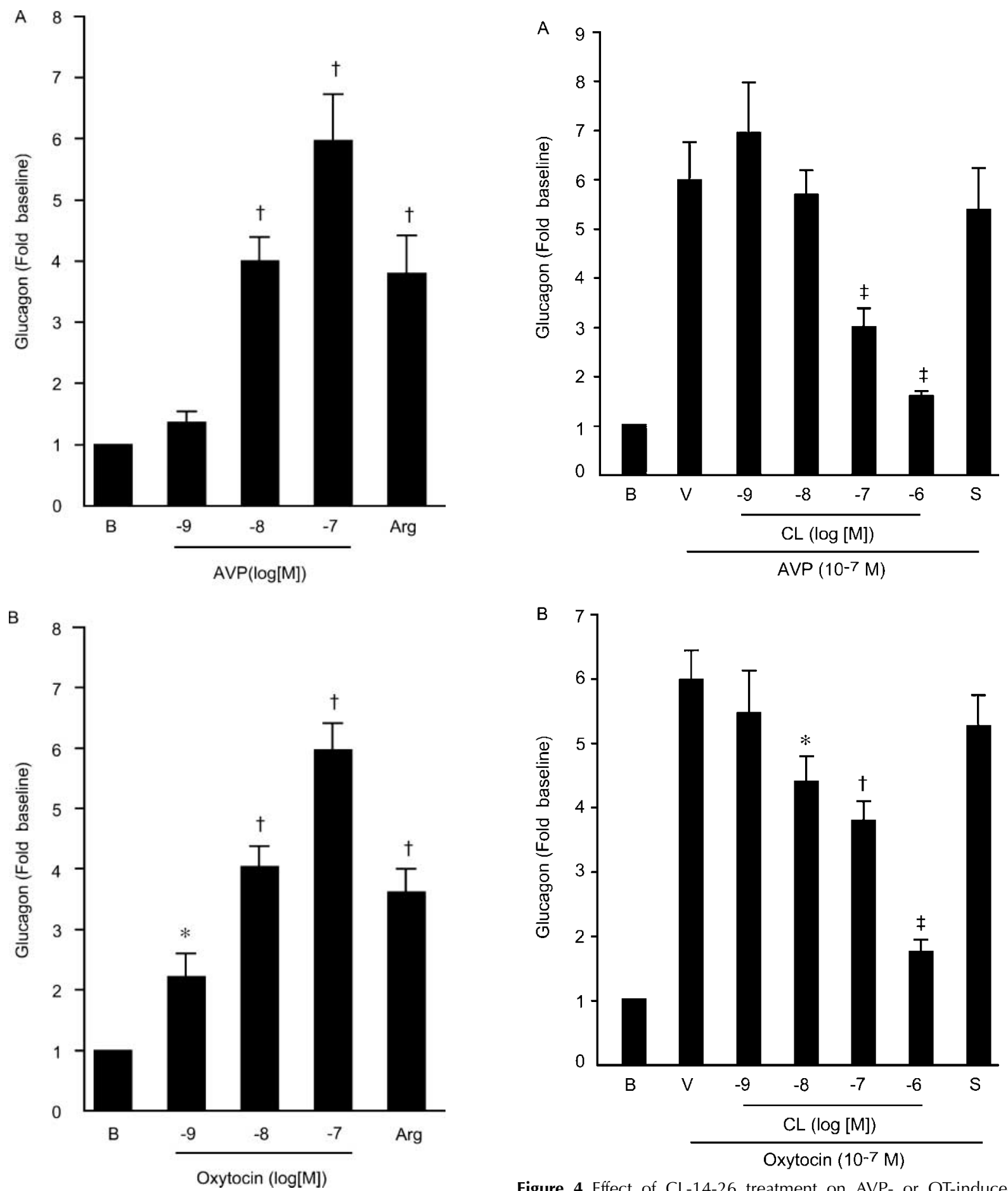

Figure 3 AVP-and OT-induced glucagon secretion from the islets of $V 1 b R-/-$ mice. (A) AVP-induced glucagon secretion. (B)

OT-induced glucagon secretion. The experiments, which included two or three assays (15 islets for each assay), were repeated four times, and the mean values and S.E.M. were calculated. B, baseline; Arg, $20 \mathrm{mM}$ arginine. ${ }^{*} P<0 \cdot 05$ and ${ }^{\dagger} P<0 \cdot 001$ versus baseline in each stimulation by a one-way ANOVA post hoc comparison with Fisher's PLSD. 
or OT, and the level was 10-12 times the value at the baseline. On the other hand, in $V 1 b R-/-$ mice, glucagon secretion was not changed, even by co-stimulation of AVP and OT (Fig. 5). These findings indicated that the effect of simultaneous stimulation of both AVP and OT was additive in $V 1 b R+/+$ mice but not in $V 1 b R-/-$ mice, suggesting that AVP and OT secreted glucagon through a single pathway, i.e. the OT receptor-mediating pathway, in $V 1 b R-/-$ mice.

\section{Discussion}

Our study shows that AVP and OT sufficiently stimulate glucagon secretion from mouse islets, as observed in previous reports (Dunning et al. 1984, Gao et al. 1991, 1992). As reported in the rat (Yibchok-anun et al. 1999), AVP- and OT-induced glucagon secretion was significantly inhibited by treatment with the $\mathrm{V} 1 \mathrm{~b}$ receptor and OT receptor antagonists

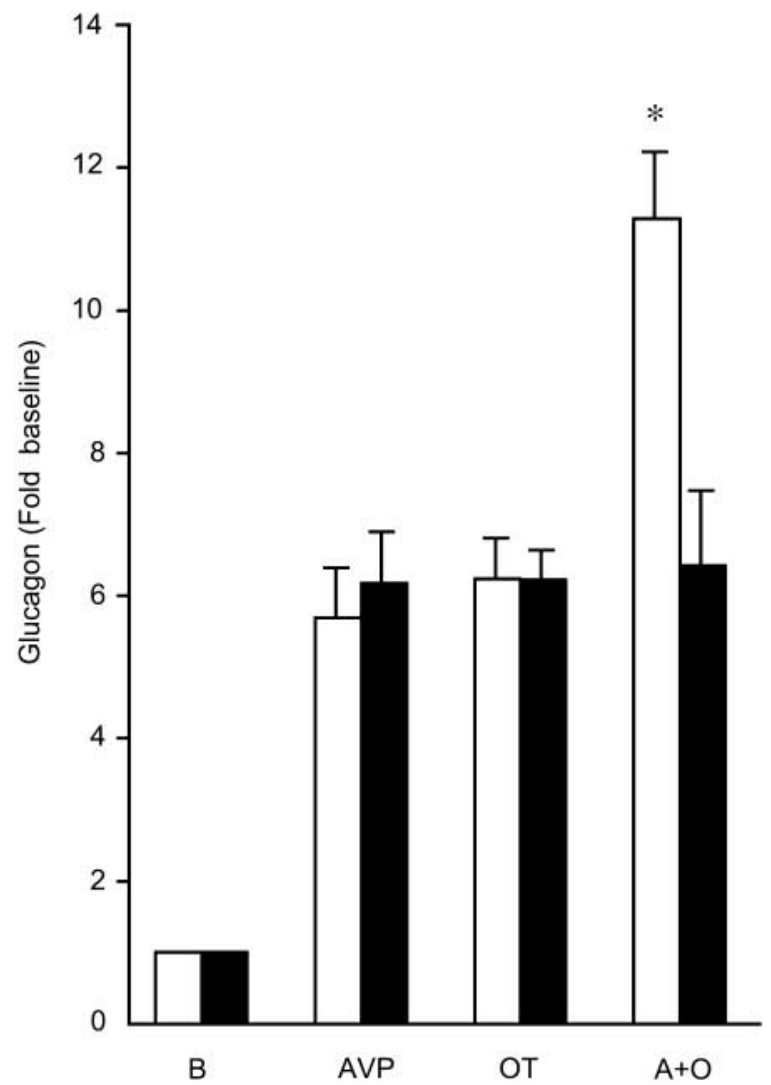

Figure 5 Co-stimulation of AVP and OT on glucagon secretion from $V 1 b R+/+$ (open bars) and $V 1 b R-/-$ (black bars) mice. The experiments, which included two or three assays (15 islets for each assay), were repeated two times, and the mean values and S.E.M. were calculated. B, baseline; AVP, $10^{-7} \mathrm{M}$ AVP; OT, $10^{-7} \mathrm{M} \mathrm{OT}$; $\mathrm{A}+\mathrm{O}$, co-stimulation of AVP and OT $\left(10^{-7} \mathrm{M}\right.$ of each). ${ }^{*} \mathrm{P}<0 \cdot 001$ versus single stimulation of AVP and OT by a one-way ANOVA post hoc comparison with Fisher's PLSD. respectively, suggesting that AVP and OT stimulate glucagon secretion via the $\mathrm{V} 1 \mathrm{~b}$ and the OT receptors respectively, in $V 1 b R+/+$ mice. However, AVP-induced glucagon secretion was not completely inhibited by $10^{-6} \mathrm{M}$ SSR149415, and co-administration of SSR149415 and CL-14-26 further inhibited AVP-induced glucagon secretion, suggesting that the OT receptors could be involved in the mediation of AVP-induced glucagon secretion. Similarly, OT-induced glucagon secretion was not completely inhibited by $10^{-6} \mathrm{M}$ CL-14-26 but was further inhibited by the co-administration of SSR149415 and CL-14-26, suggesting that the $\mathrm{V} 1 \mathrm{~b}$ receptors could also mediate OT-induced glucagon secretion. These observations suggested cross-reactivity between AVP and OT in releasing glucagon from the mouse islets. Since V1a and V2 receptors, the other vasopressin receptor subtypes, do not exist in isolated islets (Oshikawa et al. 2004), this cross-reactivity refers to the event involving V1b and OT receptors. Such crossreactivity among the receptor family for AVP and OT has been reported in several tissues. For example, OT stimulated ACTH release at the nanomolar order via the $\mathrm{V} 1 \mathrm{~b}$ receptor in primary cultured cells of the rat anterior pituitary (Schlosser et al. 1994), although OT had more than 300-fold higher affinity with the OT receptor than the $\mathrm{V} 1 \mathrm{~b}$ receptor. In other cases, the AVP acts on the OT receptor to induce the uterine contraction of nonpregnant and pregnant myometrium in mice and humans (Bossmar et al. 1994, Akerlund et al. 1999, Kawamata et al. 2003). Therefore, there could also be a crossreactivity between AVP and OT in the mouse islets. In contrast to the case of glucagon secretion, AVP could not stimulate insulin release from the islets of $V 1 b R-/-$ mice, suggesting that the $\mathrm{V} 1 \mathrm{~b}$ receptor could be essential for AVPinduced insulin secretion from the mouse islets and that receptors other than the $\mathrm{V} 1 \mathrm{~b}$ receptor could not mediate AVP-induced insulin secretion (Oshikawa et al. 2004).

The analysis of $V 1 b R-/-$ mice has revealed that AVP could sufficiently stimulate glucagon secretion under the V1b receptor-deficient condition, since AVP stimulated glucagon secretion as potently in $V 1 b R-/-$ mice as in $V 1 b R+/+$ mice. AVP-induced glucagon secretion in $V 1 b R-/-$ mice was inhibited by the OT receptor antagonist but hardly affected AVP-induced glucagon secretion in $V 1 b R+/+$ mice. These findings indicated that AVP-induced glucagon secretion via the OT receptors could be activated in $V 1 b R-/-$ mice. Thus, our study implicated that there was a crossreactivity of AVP to the OT receptor on releasing glucagon and that switching from the $\mathrm{V} 1 \mathrm{~b}$ to the OT receptors would take place under the $\mathrm{V} 1 \mathrm{~b}$ receptor-deficient condition. This is the first time that the existence of a compensating system between the V1b and the OT receptors has been revealed. On the other hand, OT has been reported to stimulate glucagon secretion via the $\mathrm{V} 1 \mathrm{~b}$ receptor in In-R1-G9, a hamster clonal $\alpha$ cell line (Yibchok-anun $\&$ Hsu 1998). Because this cell line has low affinity for OT (Folny et al. 2003), which indicates that the OT receptors could be rarely expressed in this cell line, the signaling pathways via the $\mathrm{V} 1 \mathrm{~b}$ receptors on 
OT-induced glucagon secretion could be activated in this cell line. Thus, it is likely that the compensating mechanisms between the V1b and the OT receptors could be interchangeable and that AVP and OT could have different efficacy to the $\mathrm{V} 1 \mathrm{~b}$ and the OT receptors depending on their population and predominance.

In conclusion, our studies with mutant mice and receptorselective antagonists clearly demonstrate that AVP and OT may induce glucagon secretion through a dual pathway, which is mediated by either the $\mathrm{V} 1 \mathrm{~b}$ and OT receptors or the OT receptor in the case of $\mathrm{V} 1 \mathrm{~b}$ receptor deficiency. The plasma concentration of AVP and OT is approximately $10^{-12} \mathrm{M}$ in humans (Baylis et al. 1981, Volpi et al. 1998). Since $10^{-9}-10^{-7} \mathrm{M}$ AVP and OT was used in the present study, it is unlikely that glucagon secretion occurred via the $\mathrm{V} 1 \mathrm{~b}$ and OT receptor stimulation under normal conditions. However, when diseases such as severe septic shock and congestive heart failure occur, it is known that the plasma AVP level increases approximately $10^{-11}-10^{-9} \mathrm{M}$ (Riegger et al. 1982, Lodha et al. 2006). In addition, i.v. injections of AVP and OT induce glucagon secretion in humans (Spruce et al. 1985). Thus, the cross-reactivity of V1b and OT receptors may be physiologically relevant in some severe disease cases. Our results suggest that it is necessary to consider the possibility that a substitution by other receptors of the same family is caused by the regulation of one receptor. The selective drugs targeting these two receptors could control glucagon secretion, contributing to the regulation of the blood glucose level as novel therapeutic agents.

\section{Acknowledgements}

We thank Dr M Manning for providing CL-14-26.

\section{Funding}

This work was supported by research grants from The Japan Health Sciences, the NOVARATIS Foundation, and the Takeda Science Foundation and was supported in part by a research grant from the Special Coordination Funds for Promoting Science and Technology from the Ministry of Education, Culture, Sports, Science, and Technology of the Japanese Government. The authors declare that there is no conflict of interest that would prejudice the impartiality of this scientific work.

\section{References}

Abu-Basha EA, Yibchok-anun S \& Hsu WH 2002 Glucose dependency of arginine vasopressin-induced insulin and glucagon release from the perfused rat pancreas. Metabolism 51 1184-1190.

Akerlund M, Bossmar T, Brouard R, Kostrzewska A, Laudanski T, Lemancewicz A, Serradeil-Le Gal C \& Steinwall M 1999 Receptor binding of oxytocin and vasopressin antagonists and inhibitory effects on isolated myometrium from preterm and term pregnant women. British Journal of Obstetrics and Gynaecology 106 1047-1053.
Baylis PH, Zerbe RL \& Robertson GL 1981 Arginine vasopressin response to insulin-induced hypoglycemia in man. Journal of Clinical Endocrinology and Metabolism 53 935-940.

Bossmar T, Akerlund M, Fantoni G, Szamatowicz J, Melin P \& Maggi M 1994 Receptors for and myometrial responses to oxytocin and vasopressin in preterm and term human pregnancy: effects of the oxytocin antagonist atosiban. American Journal of Obstetrics and Gynecology 171 1634-1642.

Cheng Y \& Prusoff WH 1973 Relationship between the inhibition constant (K1) and the concentration of inhibitor which causes 50 per cent inhibition $\left(\mathrm{IC}_{50}\right)$ of an enzymatic reaction. Biochemical Pharmacology 22 3099-3108.

Dunning BE, MoltzJH \& Fawcett CP 1984 Modulation of insulin and glucagon secretion from the perfused rat pancreas by the neurohypophysial hormones and by desamino-D-arginine vasopressin (DDAVP). Peptides 5 871-875.

Ecelbarger CA, Kim GH, Terris J, Masilamani S, Mitchell C, Reyes I, Verbalis JG \& Knepper MA 2000 Vasopressin-mediated regulation of epithelial sodium channel abundance in rat kidney. American Journal of Physiology. Renal Physiology 279 F46-F53.

Elands J, Barberis C, Jard S, Tribollet E, Dreifuss JJ, Bankowski K, Manning M \& Sawyer WH $1988{ }^{125}$ I-Labeled d $\left(\mathrm{CH}_{2}\right)_{5}\left[\mathrm{Tyr}(\mathrm{Me})^{2}\right.$, $\mathrm{Thr}^{4}$, Tyr$\mathrm{NH}_{2}^{9}$ ]OVT: a selective oxytocin receptor ligand. European Journal of Pharmacology 14 197-207.

Eugenin EA, Gonzalez H, Saez CG \& Saez JC 1998 Gap junctional communication coordinates vasopressin-induced glycogenolysis in rat hepatocytes. American Journal of Physiology 274 G1109-G1116.

Folny V, Raufaste D, Lukovic L, Pouzet B, Rochard P, Pascal M \& SerradeilLe Gal C 2003 Pancreatic vasopressin V1b receptors: characterization in In-R1-G9 cells and localization in human pancreas. American Journal of Physiology. Endocrinology and Metabolism 285 E566-E576.

Fuchs AR, Fuchs F, Husslein P, Soloff MS \& Fernstrom MJ 1982 Oxytocin receptors and human parturition: a dual role for oxytocin in the initiation of labor. Science 215 1396-1398.

Gao ZY \& Henquin JC 1993 Arginine vasopressin and oxytocin effects in mouse pancreatic beta-cells. Receptors involved in stimulation of insulin release. Diabetes $\mathbf{4 2}$ 914-921.

Gao ZY, Drews G, Nenquin M, Plant TD \& Henquin JC 1990 Mechanisms of the stimulation of insulin release by arginine-vasopressin in normal mouse islets. Journal of Biological Chemistry 265 15724-15730.

Gao ZY, Drews G \& Henquin JC 1991 Mechanisms of the stimulation of insulin release by oxytocin in normal mouse islets. Biochemical Journal 276 169-174.

Gao ZY, Gerard M \& Henquin JC 1992 Glucose- and concentrationdependence of vasopressin-induced hormone release by mouse pancreatic islets. Regulatory Peptides 38 89-98.

Gillies GE, Linton EA \& Lowry PJ 1982 Corticotropin releasing activity of the new CRF is potentiated several times by vasopressin. Nature 299 355-357.

Goodwin TM, Paul R, Silver H, Spellacy W, Parsons M, Chez R, Hayashi R, Valenzuela G, Creasy GW \& Merriman R 1994 The effect of the oxytocin antagonist atosiban on preterm uterine activity in the human. American Journal of Obstetrics and Gynecology 170 474-478.

Hernando F, Schoots O, Lolait SJ \& Burbach JP 2001 Immunohistochemical localization of the vasopressin V1b receptor in the rat brain and pituitary gland: anatomical support for its involvement in the central effects of vasopressin. Endocrinology 142 1659-1668.

Kawamata M, Mitsui-Saito M, Kimura T, Takayanagi Y, Yanagisawa T \& Nishimori K 2003 Vasopressin-induced contraction of uterus is mediated solely by the oxytocin receptor in mice, but not in humans. European Journal of Pharmacology 472 229-234.

Lee B, Yang C, Chen TH, al-Azawi N \& Hsu WH 1995 Effect of AVP and oxytocin on insulin release: involvement of V1b receptors. American Journal of Physiology 269 E1095-E1100.

Li G, Pralong WF, Pittet D, Mayr GW, Schlegel W \& Wollheim CB 1992 Inositol tetrakisphosphate isomers and elevation of cytosolic $\mathrm{Ca} 2+$ in vasopressin-stimulated insulin-secreting RINm5F cells. Journal of Biological Chemistry 267 4349-4356.

Lodha R, Vivekanandhan S, Sarthi M \& Kabra SK 2006 Serial circulating vasopressin levels in children with septic shock. Pediatric Critical Care Medicine 7 220-224. 
Michell RH, Kirk CJ \& Billah MM 1979 Hormonal stimulation of phosphatidylinositol breakdown with particular reference to the hepatic effects of vasopressin. Biochemical Society Transactions 7 861-865.

Moos F, Poulain DA, Rodriguez F, Guerne Y, Vincent JD \& Richard P 1989 Release of oxytocin within the supraoptic nucleus during the milk ejection reflex in rats. Experimental Brain Research 76 593-602.

Munson PJ \& Rodbard D 1980 Ligand: a versatile computerized approach for characterization of ligand-binding systems. Analytical Biochemistry 107 220-239.

Nielsen S, Chou CL, Marples D, Christensen EI, Kishore BK \& Knepper MA 1995 Vasopressin increases water permeability of kidney collecting duct by inducing translocation of aquaporin-CD water channels to plasma membrane. PNAS 92 1013-1017.

Oshikawa S, Tanoue A, Koshimizu TA, Kitagawa Y \& Tsujimoto G 2004 Vasopressin stimulates insulin release from islet cells through $\mathrm{V} 1 \mathrm{~b}$ receptors: a combined pharmacological/knockout approach. Molecular Pharmacology 65 623-629.

Richardson SB, Laya T \& VanOoy M 1995 Similarities between hamster pancreatic islet beta (HIT) cell vasopressin receptors and V1b receptors. Journal of Endocrinology 147 59-65.

Riegger GA, Liebau G \& Kochsiek K 1982 Antidiuretic hormone in congestive heart failure. American Journal of Medicine 72 49-52.

Rivier C, Rivier J, Mormede P \& Vale W 1984 Studies of the nature of the interaction between vasopressin and corticotropin-releasing factor on adrenocorticotropin release in the rat. Endocrinology 115 882-886.

Schlosser SF, Almeida OF, Patchev VK, Yassouridis A \& Elands J 1994 Oxytocin-stimulated release of adrenocorticotropin from the rat pituitary is mediated by arginine vasopressin receptors of the V1b type. Endocrinology $1352058-2063$.

Schrier RW, Briner V \& Caramelo C 1993 Cellular action and interactions of arginine vasopressin in vascular smooth muscle: mechanisms and clinical implications. Journal of the American Society of Nephrology 4 2-11.

Serradeil-Le Gal C, Wagnon J, Simiand J, Griebel G, Lacour C, Guillon G, Barberis C, Brossard G, Soubrie P, Nisato D et al. 2002 Characterization of (2S,4R)-1-[5-chloro-1-[(2,4-dimethoxyphenyl)sulfonyl]-3-(2-methoxyphenyl)-2-oxo-2,3-dihydro-1H-indol-3-yl]-4-hydroxy- N,N-dimethyl-2pyrrolidine carboxamide (SSR149415), a selective and orally active vasopressin $\mathrm{V} 1 \mathrm{~b}$ receptor antagonist. Journal of Pharmacology and Experimental Therapeutics $3001122-1130$.
Shibata A, Ludvigsen CW Jr, Naber SP, McDaniel ML \& Lacy PE 1976 Standardization of a digestion-filtration method for isolation of pancreatic islets. Diabetes 25 667-672.

Spruce BA, McCulloch AJ, BurdJ, Orskov H, Heaton A, Baylis PH \& Alberti KG 1985 The effect of vasopressin infusion on glucose metabolism in man. Clinical Endocrinology 22 463-468.

Stock S, Fastbom J, Bjorkstrand E, Ungerstedt U \& Uvnas-Moberg K 1990 Effects of oxytocin on in vivo release of insulin and glucagon studied by microdialysis in the rat pancreas and autoradiographic evidence for $\left[{ }^{3} \mathrm{H}\right]$ oxytocin binding sites within the islets of Langerhans. Regulatory Peptides $301-13$.

Tanoue A, Ito S, Honda K, Oshikawa S, Kitagawa Y, Koshimizu TA, Mori T \& Tsujimoto G 2004 The vasopressin V1b receptor critically regulates hypothalamic-pituitary-adrenal axis activity under both stress and resting conditions. Journal of Clinical Investigation 113 302-309.

Volpi R, Chiodera P, Capretti L, Caffarri G, Giuliani N, Caiazza A \& Coiro V 1998 Effect of residual endogenous insulin secretion on the abnormal oxytocin response to hypoglycaemia in insulin-dependent diabetics. Journal of Internal Medicine 244 43-48.

Yibchok-anun S \& Hsu WH 1998 Effects of arginine vasopressin and oxytocin on glucagon release from clonal alpha-cell line In-R1-G9: involvement of V1b receptors. Life Sciences 63 1871-1878.

Yibchok-anun S, Cheng H, Heine PA \& Hsu WH 1999 Characterization of receptors mediating AVP- and OT-induced glucagon release from the rat pancreas. American Journal of Physiology 277 E56-E62.

Young WS, III, Shepard E, Amico J, Hennighausen L, Wagner KU, LaMarca ME, McKinney C \& Ginns EI 1996 Deficiency in mouse oxytocin prevents milk ejection, but not fertility or parturition. Journal of Neuroendocrinology 8 847-853.

Received in final form 13 November 2006

Accepted 15 November 2006

Made available online as an Accepted Preprint 15 November 2006 